УДК 614.446:[616-085:578.828ВІЛ-053.6]

DOI https://doi.org/10.32782/humanitas/2021.5.10

\title{
Світлана САПІГА
}

кандидат педагогічних наук, старший викладач кафедри соиіальної педагогіки та соиіальної роботи, Інститут людини Київського університету імені Бориса Грінченка, вул. Бульварно-Кудрявська, 18/2, м. Київ, Україна, 04053

ORCID: 0000-0001-9805-5381

Бібліографічний опис статті: Сапіга, С. (2021). Фактори впливу на формування прихильності до антиретровірусної терапії в підлітків, що живуть із ВІЛ. Bвічливість. Humanitas, 5, 68-74, doi: https://doi.org/10.32782/humanitas/2021.5.10

\section{ФАКТОРИ ВПЛИВУ НА ФОРМУВАННЯ ПРИХИЛЬНОСТІ ДО АНТИРЕТРОВІРУСНОЇ ТЕРАПІЇ В ПІДЛІТКІВ, ЩО ЖИВУТЬ ІЗ ВІЛ}

У статті розкрито фактори впливу, які сприяють формуванню свідомої прихильності в підлітків, щчо живуть із ВІЛЛ до антиретровірусної терапії. Узагальнені результати соиіологічних досліджень, в яких висвітлюється питання аналізу причин переривання антиретровірусної терапії та відмови від антиретровірусної терапї серед людей, які живуть із ВІЛ, та узагальнено наукові праці, де охарактеризовано особливості прихильності до терапї в підлітків, щзо живуть із ВІЛ.

Представлено результати анкетного опитування, проведеного в спільноті громадського об'єднання «МО Підлітки України» з підлітками, щзо живуть із ВІЛ. Окреслено проблеми та труднощі, з якими стикаються підлітки, шзо живуть із ВІЛ. Представлено результати глибинних інтерв'ю зі спеціалістами Київського міського правобережного иентру для ВІЛ-інфікованих дітей та молоді щзодо визначення ключових факторів впливу на формування свідомої прихильності до антиретровірусної терапії. Визначено, щзо факторами впливу на формування прихильності до антиретровірусної терапії в підлітків, щзо живуть із ВІЛ, є раннє інформування дітей про їхній статус, особлива увага до формування прихильності в підлітків як групи, щчо має найбільші ризики відриву від терапї̈ на початку дорослого життя, врахування вікових особливостей у процесі розкриття ВІЛ-статусу дитини, збільшення кількості груп «рівний - рівному», соиіальний та психологічний супровід підлітків, підтримка, консультування та соиіальний супровід батьків, опікунів ВІЛ-інфікованих підлітків, роз 'яснювальна та інформаційна робота з підлітком щзодо ефективності лікування, підтримка підлітка в разі проявів побічних ефектів від прийому терапії, сприятливе та довірливе соціальне оточення, врахування стилю життя підлітка, його індивідуального режиму життедіяльності, протидія стигматизації та дискримінації за ознакою ВІЛ-статусу.

Ключові слова: прихильність, ВІЛ-статус, антиретровірусна терапія, люди, щуо живуть із ВІЛ, підлітки, щчо живуть із ВІЛ, ичентр для ВІЛ-інфікованих дітей та молоді, фактори впливу.

\section{Svitlana SAPIHA}

PhD in Pedagogy, senior teacher, Department of Social Pedagogy and Social Work, Institute of Human Sciences of Borys Grinchenko Kyiv University, 18/2 Bulvarno-Kudriavska str., Kyiv, Ukraine, 04053 ORCID: 0000-0001-9805-5381

To cite this article: Sapiha, S. (2021). Faktory vplyvu na formuvannia prykhylnosti do antyretrovirusnoi terapii u pidlitkiv, shcho zhyvut z VIL [Factors of influence on the addiction formation to antiretrovirus therapy in adolescents living with HIV]. Vvichlyvist. Humanitas, 5, 68-74, doi: https://doi.org/10.32782/humanitas/2021.5.10

\section{FACTORS OF INFLUENCE ON THE ADDICTION FORMATION TO ANTIRETROVIRUS THERAPY IN ADOLESCENTS LIVING WITH HIV}

The article reveals the influencing factors that contribute to the formation of conscious adherence in adolescents living with HIV to antiretroviral therapy. The results of sociological research are summarized, which cover the analysis of the reasons for discontinuation of antiretroviral therapy and discontinuation of antiretroviral therapy among people living with HIV and summarize scientific papers, which describe the features of adherence to therapy in adolescents living with HIV.

The results of a questionnaire survey conducted in the community of the NGO "Adolescents of Ukraine" with adolescents living with HIV are presented. The problems and difficulties faced by adolescents living with HIV are outlined. 
The results of in-depth interviews with specialists of the Kyiv City Right Bank Center for HIV-infected children and youth to identify key factors influencing the formation of conscious adherence to antiretroviral therapy are presented. It is determined that among the factors influencing the formation of adherence to antiretroviral therapy in adolescents living with HIV are: early informing children about their status; special attention is paid to the formation of attachment in adolescents, as the group with the highest risks of separation from therapy in early adulthood; taking into account age peculiarities when disclosing a child's HIV status; increasing the number of peer-to-peer groups; social and psychological support of adolescents; support and counseling and social support for parents, guardians of HIV-infected adolescents; explanatory and informational work with the adolescent on the effectiveness of treatment; support of the teenager in case of manifestations of side effects from reception of therapy; favorable and trusting social environment; taking into account the lifestyle of the adolescent, his individual lifestyle; prevention of risky behavior among adolescents living with HIV; combating stigma and discrimination on the basis of HIV status.

Key words: adherence, HIV status, antiretroviral therapy, people living with HIV, adolescents living with HIV, center for HIV-infected children and youth, influencing factors.

Постановка проблеми та ії зв'язок із важливими науковими чи практичними завданнями. Незважаючи на багаторічне впровадження профілактичних, діагностичних, клінічних, інших заходів протидії епідемії ВІЛ-інфекції, проблема ВІЛ/СНІДу залишається однією з найважливіших у світі, зокрема для України. За темпами розвитку епідемії ВІЛ/СНІД Україна посідає одне з перших місць у Східній Європі. Оціночна кількість ЛЖВ станом на 2019 рік: на диспансерному обліку в закладах охорони здоров'я на підконтрольній уряду України території перебували 137176 ВІЛ-інфікованих (71\% від оціночної кількості ЛЖВ), у тому числі 46380 хворих на СНІД. Найвищі показники поширеності ВІЛ-інфекції реєструються у 5 регіонах України: Дніпропетровській, Донецькій, Миколаївській, Одеській областях та м. Києві (Статистика, 2019).

Розширення масштабів антиретровірусної терапії (АРТ) перевело ВІЛ із невиліковної смертельної хвороби в хронічну контрольовану інфекцію. Фокус уваги поступово зміщується на необхідність забезпечення належної якості життя людей, які живуть із ВІЛ (ЛЖВ), та їх соціального супроводу та підтримки.

На жаль, невелика кількість соціологічних досліджень, проведених в Україні за останні роки, щодо потреб і проблем людей, які живуть із ВІЛ, розглядає в окремому розрізі таку категорію дітей, як підлітки. За даними державної статистики, станом на березень 2020 р. в Україні отримують АРТ 115300 ВІЛ-інфікованих людей, з яких 1612 - діти старшого віку від 11 до 18 років (Статистика, 2019).

У розрізі світової статистики дитяча та підліткова смертність, пов'язана зі СНІДом, значно знизилася серед дітей віком від 0 до 9 років (на 60\% порівняно з 2010 роком), що говорить про більш ефективну профілактику нових випадків передачі ВІЛ від матері дитині, діагностику та лікування дітей у післяпологовий період та протягом грудного вигодовування. Однак серед підлітків (віком від 10 до 19 років) прогрес повільніший, а кількість смертей, пов'язаних зі СНІДом, за той самий період скоротилася лише на 37\% (Юнейдс, 2021).

За офіційними статистичними даними (щодо осіб, що офіційно стоять на обліку), які надані обласними/міськими Центрами профілактики та боротьби зі СНІДом, загальна кількість дітей віком від 0 до 18 років, які переривали прийом АРТ понад 3 місяців, станом на 2020 рік становить 2,4\% (68 дітей). Також спеціалісти Центру роблять припущення, що є відсоток тих дітей, які не говорять зі своїм лікарем про переривання терапії або взагалі відмову від неї, тому не враховані в офіційній статистиці. Знову ж таки зазначимо, що Центри не виокремлюють підлітків в окрему групу, а подають статистику у віковому сегменті від 0 до 18 років.

Дані статистики демонструють, що саме підлітки є вкрай уразливою групою щодо інфікування ВІЛ. Вертикальний спосіб передачі вірусу залишається найпоширенішим, адже багато майбутніх матерів до останнього місяця вагітності не знають про свій ВІЛ-статус і не приймають АРТ. Незважаючи на це, підлітки також часто інфікуються ВІЛ через власну необізнаність щодо статевого життя, недовіру до батьків і лікарів, протест, емоційні зриви чи недостатнє уявлення про ризики.

Аналіз останніх досліджень і публікацій говорить про велику частку ЛЖВ, яка відмовляється від прийому АРТ. Так, за результатами дослідження Українського інституту соціальних досліджень ім. Олександра Яременка, під час якого було опитано 701 ЛЖВ, 344 особи відмовилися від АРТ (із них 90 відмовилися відразу) (Балакірєва, 2019: 25). 
Якщо подивитися на причини відмови в розрізі різних соціально-демографічних підгруп, то наймолодша група респондентів (14-29 років) частіше вказує на такі: «Не було грошей на проїзд» $(20,3 \%)$ та «Чув/ла від інших, що покращення стану здоров'я не відчувається» (майже половина молоді, 48,4\%) (Балакірєва, 2019: 29).

Ще однією проблемою, 3 якою стикаються інфіковані ВІЛ, є розкриття свого статусу іншим. Так, у молодшій віковій групі (14-29 років) майже кожен четвертий $(24,4 \%)$ респондент нікому не каже про свій статус (Балакірєва, 2019: 34).

Кожен п'ятий респондент (20\%) із числа ЛЖВ із відкритим ВІЛ-статусом (або 18\% загалом по масиву) зазначив, що хоча б раз стикався iз несанкціонованим розкриттям ВІЛ-статусу (Демченко, 2020: 28).

За статистичними даними, підлітки 3 ВІЛ рідше погоджуються з твердженням, що «ЛЖВ iз невизначуваним вірусним навантаженням (BН) на тлі регулярного прийому АРТ (із дотриманням режиму його прийому) не можуть передавати ВІЛ-інфекцію іншим», що говорить про необхідність просвітницької роз'яснювальної роботи щодо особливостей ВІЛ і АРТ (Балакірєва, 2019: 23).

Оскільки дуже важливим для лікування $\epsilon$ підлітковий вік, коли зменшується вплив батьків та їхній контроль за дотриманням режиму прийому препаратів, важливими заходами, яких необхідно вживати для формування прихильності до АРТ у підлітка з ВІЛ, якого поки що контролюють батьки, але незабаром він/ вона сам прийматиме препарати, відповідно до результатів опитування є такі: призначати прості схеми (1 таблетка на день); мати групи «рівний - рівному» для підлітків, де ВІЛ-позитивна молодь своїм прикладом надихає інших; посилити соціальний супровід підлітків (прикріплення соціального працівника); зміцнювати психологічну підтримку підлітка (підлітковий психолог, до якого можна звернутися); відновити проєкти в дитячих центрах (напр., літній табір для дітей/підлітків ВІЛ+) (Балакірєва, 2019: 92).

Також за результатами дослідження необхідним $€$ інформування дітей у родині про їхній статус - раніше, ніж вони знайдуть назви ліків в Інтернеті та зроблять хибні чи якісь неприємні для себе висновки. За даними кількісного опитування, тільки 29\% дітей віком до 14 років знають про свій статус (у тому числі тільки 57\% дітей віком від 10 років), тобто навіть для підлітків їхній статус є закритою інформацією, відповідно, ці підлітки не навчаються відповідати за своє здоров'я та не можуть впливати на перебіг лікування у разі відмови батьків від АРТ. Наголошувалося також на тому, що прихильність формується в родині і все залежить від оточення (Балакірєва, 2019).

Мета дослідження - проаналізувати проблеми та труднощі, 3 якими стикаються ВІЛпозитивні підлітки та виокремити ключові фактори, що впливають на формування прихильності до АРТ у підлітків, що живуть із ВІЛ.

Виклад матеріалу дослідження та його основні результати. Під «прихильністю терапії» нині прийнято розуміти міру участі ЛЖВ у своєму лікуванні, тобто усвідомлене пацієнтом ретельне дотримання режиму лікування.

«Прихильною» $є$ особа, що проявляє активне, стійке прагнення отримувати лікування, прагнення, засноване на усвідомленому й інформованому рішенні, прийнятому, як правило, в процесі консультування. Прихильність до терапії означає, що пацієнт свідомо, ретельно та постійно дотримується режиму лікування, а саме: вчасно приймає ліки в необхідних, призначених лікарем комбінаціях та дозах, дотримується рекомендованої кратності прийому ліків, виключаючи переривання АРТ, а також інших спеціальних рекомендацій (Бондаренко, 2015).

Недостатнє дотримання режиму лікування, низька прихильність загрожують вкрай несприятливими наслідками для ВІЛ-інфікованої особи: підвищується ймовірність неефективного лікування, є ризик виникнення стійкості до ліків, ускладняється проведення АРТ надалі, можливе подальше прогресування захворювання, знижується виживання пацієнта та підвищується ризик смерті (Бондаренко, 2015).

Прихильність $є$ частиною терапії та дуже важливою складовою частиною лікування ВІЛ. Адже, якщо в пацієнта низький рівень прихильності, це призводить до зниження ефективності лікування, а також виникнення стійких до лікування форм ВІЛ (Панфілова, 2016).

Підлітковий вік - це період від 10 до 19 років, коли люди проходять стадії фізичного, психологічного та статевого дозрівання. У підлітковому віці люди надзвичайно вразливі і схильні до 
емоційного сприйняття довкілля. Водночас це дуже продуктивний період, коли формуються віра в себе й усвідомлення свого «Я», налагоджуються дружні й романтичні відносини, розкриваються таланти й здібності, будуються плани на майбутнє й визначаються шляхи досягнення цілей - те, що стане вирішальним у побудові всього життя (Кисельова, 2019).

У підлітковому віці прийняти свій ВІЛ-статус i розкрити його іншим не легше, аніж у дорослому, адже саме цей період припадає на емоційне дозрівання, пошук і прийняття себе, що супроводжується гормональним сплеском, різкими змінами настрою, девіантною поведінкою. Іноземні дослідження показали, що розкриття ВІЛ у молодих людей не планується належним чином і іноді закінчується самогубствами, вбивствами, насильством в інтимному партнерстві та сексуальним нападом (Аріве, 2012)

Вітчизняні дослідники Т. Лях, Т. Журавель наголошують, що прихильність до АРТ у дітей та підлітків напряму залежить від рішень і поведінки дорослих. Діти можуть стати заручниками ситуацій, коли батьки повністю відмовляються від соціально-психологічної та медичної допомоги, порушують режим прийому АРТ або інші настанови лікарів, зволікають із розкриттям ВІЛ-статусу дитини (Журавель, Лях, 2016).

Дорослі особи, що виховують дітей підліткового віку (батьки, матері, опікуни тощо), здебільшого не мають коректних знань та уявлень щодо ВІЛ та контрацепції, багатьом із них не вистачає коректного розуміння питань, пов'язаних із вживанням алкоголю та інших психоактивних речовин і насильством; більше половини дорослих є носіями ірраціональних, небезпечних поглядів, переконань та настанов, що можуть спричинити їхню ризиковану поведінку. Поведінка дорослих так чи інакше відбивається на вихованні дітей, оскільки батьки або безпосередньо передають їх дітям у процесі батьківського виховання, або мимоволі транслюють їх під час спілкування 3 дітьми, виступаючи для своїх дітей моделлю для наслідування (Лютий, Петрович, 2019).

Вплив зовнішнього оточення (негативно забарвлені соціальні, медійні комунікації щодо ВІЛ-інфекції та соціальної групи ЛЖВ, міжособистісні конфлікти, упереджене ставлення в інституціях і організаціях), нестача інформації, погане фізичне самопочуття - ці та інші фактори можуть сприяти формуванню в людей, які живуть із ВІЛ, внутрішньої стигми. Це може означати відторгнення свого минулого усталеного образу (своєї тілесності, сексуальності, тих чи інших аспектів соціальної, культурної ідентичності) i конструювання негативних вимірів і означень ідентичності (наприклад, «не такий, як всі», «Хворий», «нещасний», «сам винен у своїй хворобі», «небезпечний для інших» тощо) (Демченко, 2020: 35).

Для дослідження проблем i труднощів, 3 якими стикаються ВІЛ-інфіковані підлітки, та окреслення ключових факторів формування прихильності до АРТ нами було проведено опитування 20 ВІЛ-інфікованих підлітків, членів ГО «МО Підлітки України» та проведено 5 експертних інтерв'ю $з$ спеціалістами (1 психолог, 3 фахівці з соціальної роботи (ФСР) та директорка) Київського правобережного Центру для ВІЛ-інфікованих дітей та молоді.

За результатами проведеного опитування серед ВІЛ-інфікованих підлітків ГО «МО Підлітки України» можемо виокремити труднощі та проблеми, з якими стикаються підлітки: низький рівень свідомого ставлення до власного здоров'я, некритичне відтворення підлітками практик і ставлення попередніх поколінь до ментального та фізичного здоров'я (13 респондентів); низька внутрішня мотивація/самоефективність для пожиттєвого прийому АРТ (9 респондентів); непоодинокі випадки відсутності підтримки в найближчому оточенні (11 респондентів); побічні ефекти від деяких препаратів АРТ, що негативно впливають на пам'ять, розумові здібності та розвиток загалом (12 респондентів).

При цьому варто зазначити, що більшість підлітків позитивно оцінює стан свого здоров'я (18 респондентів) і водночас зізнається, що час від часу має переривання в АРТ (13 респондентів), побічні ефекти (17 респондентів) від прийому і занадто вузький набір компетентностей та знань, у тому числі щодо комунікації з лікарем чи зі значимим дорослим щодо зміни препарату чи інших лікарських рекомендацій.

За результатами узагальнення глибинних інтерв'ю $з$ фахівцями Київського міського правобережного Центру для ВІЛ-інфікованих дітей та молоді нами були виділені фактори впливу на формування прихильності до прийому APT терапії: 
а) приділення особливої уваги формуванню прихильності в підлітків як групи, що має найбільші ризики відриву від терапії на початку дорослого життя. «Існує потреба у переглядi та удосконаленні практики доступу до якісного лікування дітей та підлітків, щчо допоможе підліткам бути свідомими в прихильності до терапії, відповідальними та створить умови для отримання фахових відповідей на потреби ВІЛ позитивних підлітків, щзо трунтуються на доказовій базі» (директорка Центру);

б) ранне інформування дітей про їхній ста$m y c$. Важливо привчити клієнта, ще в дитячому віці самостійно приймати препарати та усвідомлювати необхідність лікування. «Дорослим потрібно готувати дитину до розкриття статусу, враховуючи емочійно-психологічний стан та готовність дитини» (ФСР). Оптимальним віком для розкриття ВІЛ-статусу дитині, на думку фахівців, є 8 років;

в) врахування вікових особливостей під час розкриття ВІЛ-статусу дитини, оскільки $\epsilon$ впевненість у тому, що дитина вже знає не 3 чуток про ВІЛ. «Діти можуть заиікавитися тим, як батьки інфікувалися. Підлітки можуть проявляти негативні почуття образа, гнів - у протестній поведіниі. У будьякому разі кожна дитина насамперед потребує підтримки з боку батьків» (психолог). Для підліткового віку характерне експериментування 3 різними формами поведінки, тому важливо давати інформацію про позитивну профілактику, ризиковану поведінку, зазначаючи як негативні моменти, так і позитивні; слід зосередитись не на заборонах, а на тому, щоб навчити підлітка самостійно та відповідально приймати правильні та усвідомлені рішення. «У изьому віці на перший план виходять відносини з однолітками, тому батькам важливо повернутися до обговорення питань ведення статевого життя та звичного спілкування» (психолог);

г) збільшення кількості груп «рівний - рівному», де ВІЛ-позитивна молодь своїм прикладом надихає інших. «У таких групах для підлітків створюються безпечні, довірливі умови, без ризику витоку інформації про стан їхнього здоров'я. Підлітки, які вже мають свідому прихильність, наснажують інших підлітків своїм прикладом» (директорка Центру);

г) соиіальний та психологічний супровід підлітків. Соціальний супровід є важливою час- тиною формування прихильності до лікування. Посилення соціальної та психологічної підтримки є вкрай важливим. «Це можуть бути як штатні психологи та соціальні працівники Центрів СНІДу, так $і$ співробітники НУО, головне - ие забезпечення цього виду допомоги. У итаті Центрів із боротьби та профілактики СНІД потрібен як психолог, так $і$ соиіальний працівник, адже изе дасть змогу пацієнтам отримувати більш сталий, гарантований соиіальний супровід і психологічну підтримку» (директорка Центру). Важливий мультидисциплінарний підхід до клієнта, який значно підвищує його прихильність до лікування. Забезпечення прихильності до АРТ значною мірою залежить від формування ефективного терапевтичного альянсу, що встановлюється між ключовими фігурами лікувального процесу: лікарем, медсестрою, соціальним працівником, психологом, клієнтом;

д) постійна підтримка $і$ консультування батьків, опікунів ВІЛ-інфікованих підлітків, їх соиіальний супровід на всіх рівнях. Тут, як акцентують спеціалісти, «важливий міжсекторальний підхід $і$ включеність у процес всіх установ, иентрів, НУО, де отримує сочіальні послуги родина підлітка з ВІЛ» (ФСР). Складниками підтримки батьків можуть бути: забезпечення конфіденційності, спостереження за дитиною після розкриття статусу, запобігання нехтування потребами дитини, психологічна та соціальна підтримка сім'ї. «Консультування має бути спрямоване на покращення сімейного клімату, вирімення конфліктних ситуацій, виявлення ресурсів, які можуть бути залучені або знайдені, для підтримки не лише сім'ї загалом, а й самого підлітка» (ФСР);

е) роз'яснювальна та інформаційна робота з підлітком щзодо ефективності лікування. Важливий доступ підлітка до якісної та доказової інформації щодо перебігу своєї хвороби. «Більш ймовірно, що підліток, який вірить в ефективність свого лікування, досягне вищих рівнів прихильності, ніж той, чиє ставлення скептичне чи мінливе» (психолог);

є) підтримка підлітка в разі проявів побічних ефектів від прийому терапії. Деякі побічні ефекти є досить серйозною проблемою відразу після початку лікування, проте пізніше, як правило, через короткий період часу, вони проходять. «Важлива підтримка з боку оточуючих 
y періоди проявів побічних ефектів із боку родини або групи підтримки. Вкрай необхідним є формування довірливих стосунків із лікарем задля обговорення свого стану $і$ можливої зміни схем терапї̈》 (ФСР);

ж) сприятливе та довірливе соиіальне оточення. Стабільні і довірливі відносини в сім'ї, з друзями, однокласниками можуть позитивно впливати на успішність прихильності до лікування;

з) урахування стилю життя підлітка, його індивідуального режиму життєдіяльності перед призначенням терапії. «Найбільш ймовірно, щзо клієнт прийматиме препарати регулярно, якщо вони вписуються у його спосіб життя та режим» (психолог). Рішення про початок лікування має прийматись на індивідуальній основі, враховуючи особисті обставини, такі як графік роботи або іншу діяльність;

u) профілактика ризикованої поведінки серед підлітків, щуо живуть із ВІЛ. Вживання психоактивних речовин $є$ сильним фактором впливу на перерви, пропуски та відмову від терапії. Тому важливим є проведення систематичних профілактичних заходів серед підлітків, що живуть із ВІЛ;

i) протидія стигматизаиіï, внутрішня стигма, дискримінації за ознакою ВІЛ-статусу. Важливою проблемою залишається стигматизація хвороби та дискримінація ВІЛ-інфікованих у різних сферах життя (медицина, освіта, культура тощо), а тому інформування та зменшення міфів навколо ВІЛ $\epsilon$ важливою передумовою зменшення дискримінації, що своєю чергою вплине на прихильність клієнта до прийому АРТ.

Висновки i перспективи подальших досліджень. Формування прихильності до АРТ у підлітків як групи, що має найбільші ризики відриву від терапії на початку дорослого життя, є вкрай важливим. Ця вікова група має низький рівень свідомого ставлення до власного здоров'я, низьку внутрішню мотивацію для пожиттєвого прийому АРТ, вузький набір компетентностей та знань, у тому числі стосовно комунікації з лікарем чи значимим дорослим щодо зміни препарату чи інших лікарських рекомендацій. За умов відсутності підтримки в найближчому оточенні та наявної стигми та дискримінації в суспільстві щодо людей, які живуть із ВІЛ, підліткам із ВІЛ важко сформувати свідому прихильність до прийому АРТ. Тому важливими факторами формування прихильності постають раннє інформування дітей про їхній статус, врахування вікових особливостей під час розкриття ВІЛ-статусу дитини, збільшення кількості груп «рівний - рівному», соціальний та психологічний супровід підлітків; підтримка і консультування та соціальний супровід батьків, опікунів ВІЛ-інфікованих підлітків, роз'яснювальна та інформаційна робота 3 підлітком щодо ефективності лікування, підтримка підлітка в разі проявів побічних ефектів від прийому терапії, сприятливе та довірливе соціальне оточення, врахування стилю життя підлітка, його індивідуального режиму життєдіяльності, протидія стигматизації та дискримінації за ознакою ВІЛ-статусу.

Дискусійними та такими, що потребують подальшого обговорення в контексті цього дослідження, можуть бути дослідження чинників та причин переривання АРТ у підлітків із ВІЛ, оцінка ефективності діяльності мультидисциплінарних команд із забезпечення медико-соціальної допомоги ВІЛ-інфікованим дітям та їхнім сім'ям, дослідження чинників формування прихильності до АРТ у вагітних, які не хочуть приймати терапію, нехтуючи можливістю народження здорової дитини.

\section{ЛІТЕРАТУРА:}

1. Балакірєва О., Бондар Т., Шевченко С. Дослідження «Поведінкове дослідження аналізу причин переривання антиретровірусної терапії та відмови від антиретровірусної терапії серед людей, які живуть із ВІЛ, та дітей». Київ, 2019. URL: https://phc.org.ua/sites/default/files/users/user90/Prychyny_pereryvannia_ART_report.pdf.

2. Бондаренко А., Козько В., Гвоздецька М., Юрко К., Черкасов О. Оцінка прихильності до антиретровірусної терапії у хворих на ко-інфекцію HIV/HBV. 2015. URL: http://ns1.knmu.edu.ua/bitstream/.

3. Демченко I., Скокова Л., Булига Н. Індекс стигми людей, які живуть з ВIЛ 2.0. Україна. 2020. URL: https://network.org.ua/wp-content/uploads/2021/02/INDEKS-STYGMY-LYUDEJ-YAKI-ZHYVUT-Z-VIL-2.0-1-1.pdf.

4. Журавель Т., Лях Т. Особливості соціально-психологічної підтримки осіб та сімей, які живуть з ВІЛ/ СНІД в Україні. Педагогічні науки: теорія, історія, інноваиійні технології. 2015. № 8. С. 323-333. URL: https://elibrary.kubg.edu.ua/id/eprint/14613/. 
5. Кисельова Г., Бейлі Х. Молодь, яка живе з ВІЛ, в Україні: Реалії, виклики, шляхи подолання. 2019. URL: https://www.unicef.org/ukraine/media/2891/file/HIV_Youth.pdf

6. Лютий В., Петрович В. Профілактика ВІЛ та соціально-небезпечних явищ серед дорослих: досвід «Програми 15». Науковий вісник Східноєвропейського наиіонального університету імені Лесі Украйнки. Серія: Педагогічні науки. 2019. o 2(386). С. 91-103. URL: https://elibrary.kubg.edu.ua/id/eprint/27894/.

7. Панфилова О., Валько С., Медко А. Основные аспекты в раскрытии ВИЧ-позитивного статуса ребенку и формирование приверженности к АРВ-терапии у детей, живущих с ВИЧ. Тренинговый модуль. 2016. URL: https://teenergizer.org/media/2017/08/Metodichka_Tinerdzhai-zer-2.pdf

8. Статистика з ВІЛ/СНІДу. Епідемічна ситуація з ВІЛ-інфекції в Україні станом на 01.04.2019 p. URL: https://phc.org.ua/kontrol-zakhvoryuvan/vilsnid/statistika-Z-vilsnidu.

9. ЮНЕЙДС (2021). Медленный прогресс в предотвращении смертельных случаев, связанных со СПИДом, среди подростков. URL: https://www.unaids.org/ru/resources/presscentre/featurestories/2021/october/20211004_aidsrelated-deaths-among-adolescents.

10. Arrivé, E., Ayaya, S., Davies, M. A., Chimbetete, C., Edmonds, A., Lelo, P., \& Leroy, V. (2018). Models of support for disclosure of HIV status to HIV-infected children and adolescents in resource-limited settings. Journal of the International AIDS Society, 21(7).

\section{REFERENCES:}

1. Balakirieva O., Bondar T., Shevchenko S. (2019). Doslidzhennia «Povedinkove doslidzhennia analizu prychyn pereryvannia antyretrovirusnoi terapii ta vidmovy vid antyretrovirusnoi terapii sered liudei, yaki zhyvut z VIL, ta ditei». Retrieved from: https://phc.org.ua/sites/default/files/users/user90/Prychyny_pereryvannia_ART_report.pdf. [in Ukrainian].

2. BondarenkoA., Kozko V., Hvozdetska M., Yurko K., Cherkasov O. (2015). Otsinka prykhylnosti do antyretrovirusnoi terapii u khvorykh na ko-infektsiiu HIV/HBV. Retrieved from: http://ns1.knmu.edu.ua/bitstream/. [in Ukrainian].

3. Demchenko I., Skokova L., Bulyha N. (2020). Indeks styhmy liudei, yaki zhyvut z vil 2.0. Ukraina. Retrieved from: https:// network.org.ua/wp-content/uploads/2021/02/INDEKS-STYGMY-LYUDEJ-YAKI-ZHYVUT-Z-VIL-2.0-1-1.pdf. [in Ukrainian].

4. Zhuravel T., Liakh T. (2016) Osoblyvosti sotsialno-psykholohichnoi pidtrymky osib ta simei, yaki zhyvut z VIL/ SNID v Ukraini. Retrieved from: https://elibrary.kubg.edu.ua/id/eprint/14613/. [in Ukrainian].

5. Kyselova H., Beili Kh. (2019). Molod, yaka zhyve z VIL, v Ukraini: Realii, vyklyky, shliakhy podolannia. Retrieved from: https://www.unicef.org/ukraine/media/2891/file/HIV_Youth.pdf. [in Ukrainian].

6. Liutyi V., Petrovych V. (2019) Profilaktyka VIL ta sotsialno-nebezpechnykh yavyshch sered doroslykh: dosvid «Prohramy 15». Retrieved from: https://elibrary.kubg.edu.ua/id/eprint/27894/. [in Ukrainian].

7. Panfilova O., Val'ko S., Medko A. (2016). Osnovnyye aspekty v raskrytii vichpozitivnogo statusa rebenku i formirovaniye priverzhennosti k ARV-terapii u detey, zhivushchikh s VICH. Treningovyy modul'. Retrieved from: https://teenergizer.org/media/2017/08/Metodichka_Tinerdzhai-zer-2.pdf. [in Ukrainian].

8. Statystyka z VIL/SNIDu. Epidemichna sytuatsiia z VIL-infektsii v Ukraini stanom na 01.04.2019. Retrieved from: https://phc.org.ua/kontrol-zakhvoryuvan/vilsnid/statistika-z-vilsnidu. [in Ukrainian].

9. YuNEYDS (2021). Medlennyiy progress v predotvraschenii smertelnyih sluchaev, svyazannyih so SPIDom, sredi podrostkov. Retrieved from: https://www.unaids.org/ru/resources/presscentre/featurestories/2021/october/20211004_ aids-related-deaths-among-adolescents. [in Ukrainian].

10. Arrivé, E., Ayaya, S., Davies, M. A., Chimbetete, C., Edmonds, A., Lelo, P., \& Leroy, V. (2018). Models of support for disclosure of HIV status to HIV-infected children and adolescents in resource-limited settings. Journal of the International AIDS Society, 21(7). 